Review

\title{
Palaeoart at Two Million Years Ago? A Review of the Evidence
}

\section{James B. Harrod}

Center for Research on the Origins of Art and Religion; Maine College of Art, Portland, ME 04102, USA; E-Mail: jbharrod@ midmaine.com; Tel.: +1-207-553-2048

Received: 29 September 2013; in revised form: 22 November 2013 / Accepted: 26 November 2013 / Published: 28 February 2014

\begin{abstract}
Current archaeological evidence supports the claim that symbolic behavior, including palaeoart, first emerged in human evolution around 1 million years ago. The purpose of this article is to review archaeological studies that might support the hypothesis that the earliest palaeoart actually is evident around 2 million years ago. This review identifies nine Oldowan artifacts that have been proposed as possible non-utilitarian and possibly symbolic behavior. Among seven stone tools, the three strongest candidates are the Olduvai Gorge, the FLK North grooved and pecked cobble, 1.80 million years ago, and MNK Main subspheroid with hexagon shape framing an apparent natural dot-and-undulating-line motif, $\sim 1.5-1.6$ million years ago, both initially reported and described by Mary Leakey; and the curated Koobi Fora FxJj1 "broken core" with inner rhomboid shape, $\sim 1.87$ million years ago. All six stone tools from Olduvai Gorge need scientific re-examination to determine their chaîne opératoire and assess non-utilitarian features. If even one of the Olduvai Gorge artifacts were validated as symbolic behavior this would indicate the emergence of palaeoart one million years earlier than current proposals. It would also suggest that Homo habilis/rudolfensis or a very early Homo erectus had substantially more advanced cognitive, design and symbolic competencies than inferred in current theories. It would constitute a challenge to develop more advanced cognitive semiotic and art-theoretic analytical tools for illuminating the role of such palaeoart in hominin cultural evolution.
\end{abstract}

Keywords: origin of art; rock art; palaeoart; symbolic behavior; Oldowan; Lower Palaeolithic; Africa; prehistory of art; art history; cultural evolution 


\section{Introduction}

The discussion of whether or not Homo habilis or a sister species engaged in symbolic behavior during the Oldowan period is ongoing. Hypotheses have been suggested from the fields of palaeoanthropology, paleoneurology, cognitive psychology and linguistics, and by using analogies from the fields of primatology, child development and cognitive neuroscience. This study aims to widen the conversation between art and science and indicate the potential to substantially lengthen the archaeological time-span for the evolution of palaeoart and other symbolic behaviors.

The possibility that certain Oldowan artifacts might evidence non-utilitarian symbolic behavior seems to have been last noted by Ashley Montagu (1976) [71] and Stephen Edwards (1978) [29]. Montagu mentions one Oldowan artifact, the Olduvai Gorge, FLK North-1 grooved and pecked cobble as non-utilitarian citing Mary Leakey (1971) [59], noting that she compared it to the Makapansgat cobble and speculated that the markings resulted in a resemblance to a baboon head, and Montagu refers to it as an example of "mental development" (267). Similarly, Edwards' review of Lower Paleolithic "non-utilitarian behavior" lists examples from the Acheulian period and for the Oldowan mentions the FLK North grooved and pecked cobble, suggesting it should not be ignored and cannot be "in no way evidence" (136). In current debates about the emergence of hominin symbolic behavior, this and other possible non-utilitarian Oldowan artifacts are not discussed and remain to be scientifically examined and alternative explanations ruled out.

Hypotheses for the date for the emergence of intentionally-worked hominin "art" or "symbolism" range from the Upper Paleolithic/Later Stone Age, 50 thousand years ago (ka), to the Middle Paleolithic/Middle Stone Age, e.g., beads, incised ochre at Blombos Cave, South Africa, $75 \mathrm{ka}$, and deeper in time to the Middle Acheulian period around 1 million years ago (Ma).

A brief up-to-date review of Lower Palaeolithic archaeological evidence for hominin palaeoart and other symbolic behaviors follows. The earliest evidence is from around 2.6 million years ago (Ma) Makapansgat figurine manuport with natural pareidolic face, "eyes" and "mouth" [8,17,24,52]. As it is -natural, this might be considered a found art object. It places curation, pareidolia and natural iconic figuration at the beginning of hominin symbolic behavior.

Middle as well as Early Acheulian period evidence occurs in Africa, including pigments, e.g., red ochre, Wonderwerk Cave Units 6 and 7, 1.17 Ma and Kathu Pan 1, 800-900 ka (reviews of African palaeoart: [3,17]). In southwest Asia, Gesher Benot Ya'aqov, 750-800 ka [42], reports small angular, unworn, quartz crystals and two naturally perforated bead-like circular crinoid fossil casts natural to the site) [43], worn on their sides, apparently due to being in contact with other beads [18]. From the same site there are a few cleavers among hundreds of bifacial tools in which the knapper appears to have preserved and enhanced the basalt vesicles (e.g., Goren-Inbar and Sharon 2006: cover) [44], which is "most remarkable" since all other bifaces were made from homogenous material (N. GorenInbar, email to author, 31 October 2010). While there is as yet no other archaeological support for intentionality and none for symbolism, these bifaces appear, at least to me, to have pareidolic face-like features evoked by the knappers unusual preservation of two vesicles for "eyes" and other flaking features adding to the impression of a "nose" or "mouth".

Six manuported quartz crystals occur at Singi Talav, India (Gaillard et al. 1983; d'Errico et al. 1989; Bednarik 2013) [18,26,39], 800 ka (Gaillard et al. 2010) [35]. At Auditorium Cave, 
Bhimbetka, Madhya Pradesh, India, site III-F24, a cupule-and meandering-groove petroglyph occurs in upper Acheulian Level 5, and based on how cupules are made, the petroglyph was more likely made by occupants of lower Acheulian Level 6 or Level 8, which has Oldowan-like cobble chopper tools and scrapers (Bednarik 2013, 2006, 2005; design analysis, Harrod 2007) [14,15,18,48]. A vertical cupule panel also occurs in Auditorium Cave and a cupule panel at Daraki-Chattan, India associates to an industry with cobble tools, discoids and no bifaces (Kumar 1996; Bednarik 1996) [6,57]. In India "chopper-chopping tool" reduction occurs in conjunction with large flake tool reduction at Early Acheulian sites as early as Attirampakkam, 1.5 Ma (Pappu et al. 2011) [75]. Apparently non-utilitarian, patterned incisions on bones occur in Kozarnika, Bulgaria, Layer 12, 1.4-1.6 Ma, with "core-and-flake" non-pebble tools (Guadelli 2004; Sirakov et al. 2010) [46,79], though dating is faunal with no numerical age (Parés 2013) [76].

More frequent evidence occurs by the Later Acheulian period in Africa, e.g., Tan-Tan figurine, 300-500 ka (Bednarik 2001, 2003, 2013) [9,12,17]; Erfoud figurine, Morocco, 200-300 ka (Bednarik 2002) [10]; cupule petroglyphs at Nchwaneng, Kalahari, linked to Middle Fauresmith (Beaumont and Bednarik 2013; Bednarik 2013) [3,17]; ostrich eggshell beads at El Greifa, Libya, 200 ka (Bednarik 1997) [7]. Abundant red and other colored ochres and specularite pigment occur at multiple Later Acheulian and Fauresmith sites in Africa (Beaumont and Bednarik 2013; Bednarik 2013; Bednarik 1990) [3,4,17]; and in Southwest Asia, e.g., Berekhat Ram figurine, integrated age 470 ka (Goren-Inbar 1986, 1995; Marshack 1997; d'Errico and Nowell 2000) [27,40,41,63]. Highly aesthetic Later Acheulian bifaces occur at multiple sites in Africa, Europe and Asia. Europe, e.g., cordiform with worked "eye" on vertical axis upper, La Morandiére, Loire-et-Cher, 520-730 ka (Despriée et al. 2009) [28], and I note that this figure also illustrates an apparently hexagonally flaked core, though this may be simply a non-intentional by-product of ordinary flaking; Swanscombe handaxe worked with five-pointed sea urchin at its plan face center, with two exotic manuported fivepoint "starrystone" fossils, 400 ka (Oakley 1981, 1973) [73,74]; red-brown amygdaloid biface deposited in human skeleton/bone deposition, Sima de los Huesos, Spain, 400-500 ka (Carbonell et al. 2003) [20]; West Tofts, 200 ka handaxe with fossil scallop shell plan face center (Oakley 1981, 1973; design analysis, Feliks 2008, 2006, 1998) [34-36,73,74] and Cuxton, $\sim 230 \mathrm{ka}$, perfectly symmetrical giant handaxe and cleaver pair (Wenban-Smith 2004) [87]. Examples of other types of palaeoart from Later Acheulian period Europe include the sophisticated incised markings on bone and stone, Bilzingsleben, 350-420 ka (Mania and Mania 1988; Steguweit 1999; phi golden ratios, Feliks 2008) [36,62,81]; 2 Porosphaera globularis fossil sponge beads, Bedford, 400 ka (Rigaud et al. 2009) [78]; and partly natural, partly enhanced artifacts with suggested zoomorphic and anthropomorphic figuration, Hamburg-Wittenbergen, 230 ka (Matthes 1969, 1964/65, 1963) [64-66].

Between the early Acheulian evidence for palaeoart, including pigments and exotic crystals around $1 \mathrm{Ma}$ (and possibly incised markings on the Kozarnika bone $\sim 1.5 \mathrm{Ma}$ ), and the all-natural but curated Makapansgat manuport at $2.6 \mathrm{Ma}$, there appears to be a gap of a million years. The purpose of this literature review is to identify proposed candidates for Oldowan palaeoart, which, though they have not been adequately verified by current scientific standards, have potential for providing evidence to fill this million-year gap. 


\section{Method}

I conducted a review of literature pertaining to African Oldowan archaeology to identify artifacts that have been reported to be apparently "non-utilitarian", "symbolic behavior", "palaeoart" or "unusual" ("non-ordinary"). To conduct such a literature review requires a definition of "symbolic behavior" or "palaeoart". Rather than a generic or essentialist definition, I developed a checklist of types of such behavior, and used this to screen the literature. This list refines the categories in Harrod (2010) [46], which drew on, and added to, categories of "symbolic behavior" in McBrearty and Brooks (2000: p. 518) [70] and "palaeoart" in Bednarik (2013a, 2013b, 2003, 1995) [5,11,17,18] as well as adding terminology from the IFRAO Rock Art Glossary (Bednarik 2003/2013) [13]. To put the list in a primate and child development art-theoretic perspective I add the concept of "trace-making" from Matthews (2011, 1997, 1994) [67-69] (Table 1). Any given object may incorporate more than one category of symbolic behavior.

The term "palaeoart" appears generally applied to the subset of symbolic behavior categories \#1 through \#7, although I see no rationale to exclude categories \#8-10 from the subset of "palaeoart". In reviewing this list, I observe that categories \#3 through \#10 share the behavior of intentional placement of marks or designs on a medium (artifact). This we might term palaeoart sensu stricto. Conversely, categories \#11 through \#13 are a subset that shares the behavior of intentional placement of objects, whether artifacts or geofacts, as markers to reveal, presence or bring into presentation aspects of the environment ("aesthetic" of a landscape, world, cosmos). Categories \#14 and \#15 might be included in this subset if viewed as manifesting auditory, tactile, graviceptive, and proprioceptive or vestibular sensory markers of environing space. Reflecting on this list, the symbolic behaviors of "curation", "making a trace" and spoken or protolanguage seem to be at a higher level than \#3 through \#15, and encompass or permeate all of these categories. The implications of this for the definition of "art" I leave for another time.

It may be objected that one cannot speak of symbolic behavior without specifying a referrer and referent. From one pragmatics perspective a symbol is a sign, the components of which are the signifier, the semantic signified and a referent. The signified may be singular or multiple semantic meanings. Among contemporary sapiens sapiens and by at least one classification, the association of signifier and signified may be iconic, indexical or conventional. Signs may be called representational. Signs play a role in analogies and rhetorical conventional metaphors (epiphors). From another pragmatics perspective a symbol or symbolic form evokes an idea, quality, value, emotion, feeling, mood or state of being, which it is said to "symbolize". It is a presentational and contextual (whether neutral, fictional, or binary opposites) evocation of a theme and its variations and may be subject to a sequence of transformations. Symbols may include designs, tokens or emblems whose primary function is evocative. In contrast to signs, symbols play a role in depth metaphors (diaphors). In either pragmatics perspective to infer a referent is an act of interpretation. In this literature review my procedure is to look for artifacts classifiable as symbolic behavior without: (a) distinguishing between these two contrasting categories of signs; or (b) inferring a referent or elaborating an interpretation of "meaning" or function. Interpretation requires a separate discussion of hermeneutics and is a topic beyond the scope of this review. 
Table 1. Symbolic behavior-taxonomy.

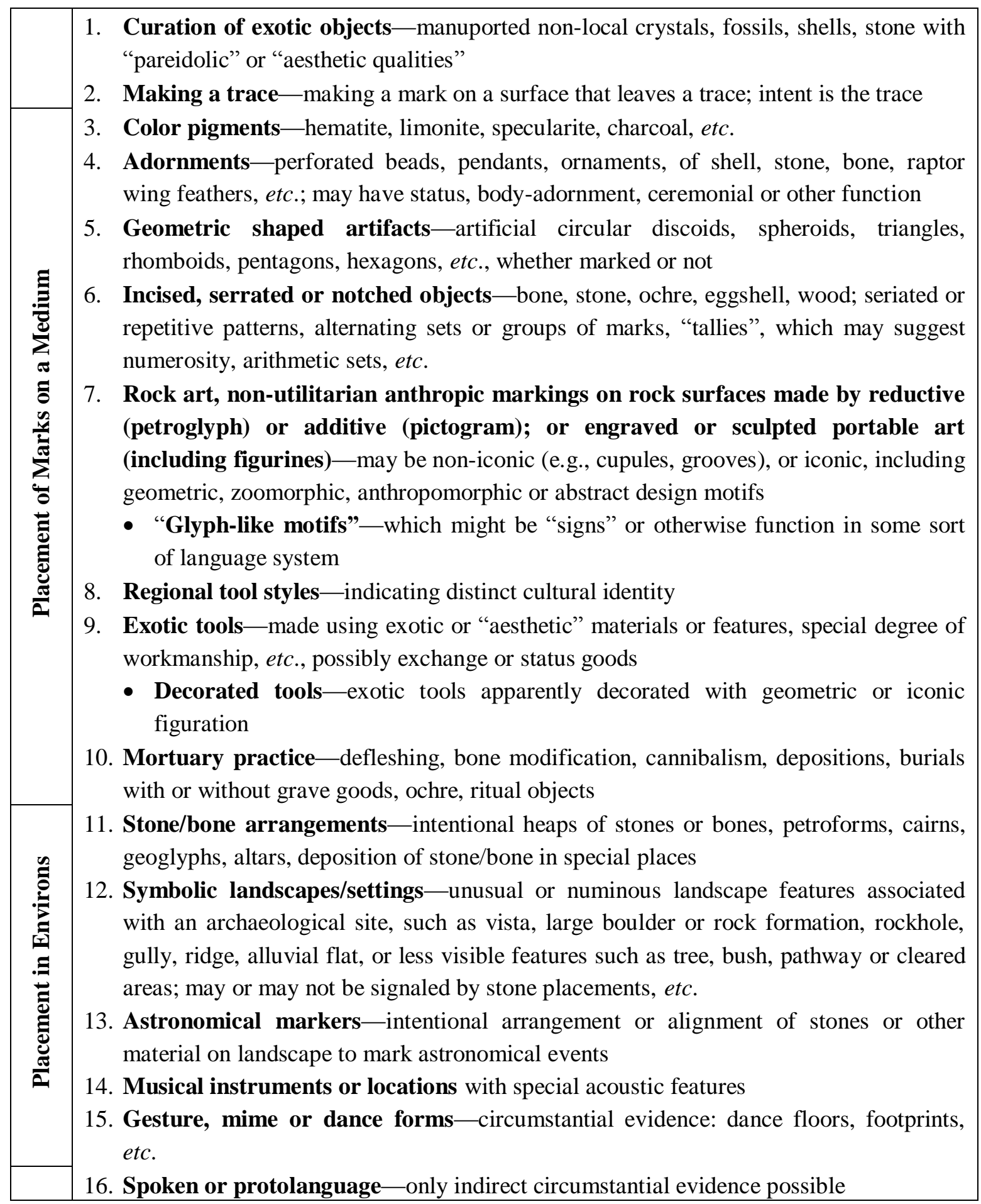

With respect to any proposed object and for each category, to establish symbolic intent requires first determining whether, or to what degree, the object is an artifact or geofact (nature-fact) and if it has artificial working traces whether they are intentional or accidental. Determination must be made whether the object is utilitarian (usually considered to mean "tool") or non-utilitarian ("not a tool" and not simply toolmaking "waste" or tool use "damage" or "battering"). Of course, an artifact may be classed as a decorated tool with utilitarian and non-utilitarian aspects. If there appear to be markings or 
marker placements it must be verified microscopically or otherwise that to what degree they are totally natural, natural and artificially enhanced, or fully artificial. Both symbolic and non-symbolic alternative explanations must be hypothesized, and the non-symbolic explanations ruled out to rule in possible symbolic behavior. For example, an artifact such as a marine shell might be alternatively a utilitarian tool or container or a curated exotic object (manuport) or an ornamental pendant. In this case, if the first two alternatives are ruled out, and one or the other symbolic behaviors ruled in, this results in only a categorical classification as symbolic. Determination of "symbolic function" (e.g., social status, identity signal, component of cultural ritual, etc.) and "symbolic meaning" or "interpretation of meaning" (semantic, thematic, metaphoric, emotionally evocative, etc.) may be left as indeterminate or pursued by a clear methodology, which itself must be justified and appropriate to the artifact's evolutionary context.

\section{Results}

This review identified nine African Oldowan candidates that have been proposed or appear to be possible candidates for non-utilitarian Oldowan symbolic behavior, and with exception of language, palaeoart. These are listed in Table 2. With respect to each candidate in this list, I reiterate that it is only a putative candidate for symbolic behavior based on a review of the literature. Each needs to be scientifically re-examined to determine the extent of evidence for ruling it in or out as symbolic behavior.

Table 2. Putative candidates for Oldowan symbolic behavior.

\begin{tabular}{|c|c|c|}
\hline Symbolic Behavior & Site and Date & Artifact \\
\hline $\begin{array}{l}\text { Curation of exotic object }+ \\
\text { exotic tool }+ \text { geometric shape }\end{array}$ & $\begin{array}{c}\text { FxJj1 (KBS), Koobi Fora, 1.87 Ma, } \\
\text { Classic Oldowan }\end{array}$ & $\begin{array}{c}\text { Broken/irregular chopper } \\
\text { ("rhomboid-in-a core") on basalt } \\
\text { pebble core, curated }\end{array}$ \\
\hline \multirow{2}{*}{$\begin{array}{c}\text { Rock art, glyph-like motifs }+ \\
\text { geometric shaped artifact } \\
\text { (numerosity?) }\end{array}$} & $\begin{array}{c}\text { FLK North 1, Upper Bed I, 1.80 Ma, } \\
\text { Olduvai Gorge, } \\
\text { Classic Oldowan }\end{array}$ & $\begin{array}{l}\text { Artificially grooved and pecked } \\
\text { phonolite cobble (incised circular } \\
\text { groove, cupules) }\end{array}$ \\
\hline & $\begin{array}{l}\text { MNK Main, Middle Bed II, } \\
\sim 1.5-1.6 \mathrm{Ma} \text {, Olduvai Gorge, Dev. } \\
\text { Oldowan/Early Acheulian }\end{array}$ & $\begin{array}{c}6.6 \mathrm{~kg}(14.5 \mathrm{lb} .) \text { subspheroid with } \\
\text { apparent natural marking (dot and } \\
\text { undulating line), possibly framed } \\
\text { by hexagonal flaking }\end{array}$ \\
\hline \multirow[b]{2}{*}{ Geometric shaped artifact } & $\begin{array}{c}\text { FLK North Clay - Root Casts, Lower } \\
\text { Bed II, } \sim 1.74-1.80 \mathrm{Ma}\end{array}$ & $\begin{array}{l}\text { Anvil, hexagonal block, quartzite } \\
\text { (battered or flaked shape?) }\end{array}$ \\
\hline & $\begin{array}{c}\text { FLK North Sandy Congl. 6, } \\
\text { Middle Bed II, 1.6-1.66/1.74 Ma, } \\
\text { Developed Oldowan A }\end{array}$ & $\begin{array}{l}\text { Anvil, hexagonal block, } \\
\text { hornblende gneiss } \\
\text { (battered or flaked shape?) }\end{array}$ \\
\hline \multirow{2}{*}{$\begin{array}{c}\text { Exotic tool, non-iconic } \\
\text { ("exaggerated anvil pit") + } \\
\text { geometric shaped } \\
\text { (concentric circles) } \\
\text { or rock art (cupule) }\end{array}$} & $\begin{array}{c}\text { FLK North 1, Upper Bed I, } ~ 1.80 \mathrm{Ma}, \\
\text { Olduvai Gorge, } \\
\text { Classic Oldowan }\end{array}$ & $\begin{array}{l}\text { Pitted anvil, conical block, pecked } \\
\text { pit } 29 \times 17 \mathrm{~mm} \text {, depth } 9 \mathrm{~mm}\end{array}$ \\
\hline & $\begin{array}{l}\text { FLK North Sandy Conglomerate 6, } \\
\text { Middle Bed II, 1.6-1.66/1.74 Ma, } \\
\text { Developed Oldowan A }\end{array}$ & $\begin{array}{l}\text { "Unusual anvil", with } \\
\text { pit } 35 \times 24 \mathrm{~mm} \text {, depth } 5 \mathrm{~mm} \text { in } \\
\text { center of one face }\end{array}$ \\
\hline
\end{tabular}


Table 2. Cont.

\begin{tabular}{|c|c|c|}
\hline Symbolic Behavior & Site and Date & Artifact \\
\hline Mortuary practice & Sterkfontein M5A, 1.40-1.78 Ma & $\begin{array}{c}\text { Hominin maxilla (H. habilis?) } \\
\text { with stone tool cutmarks, "earliest } \\
\text { evidence of post-mortem } \\
\text { manipulation of hominid carcass } \\
\text { by other hominids" }\end{array}$ \\
\hline Spoken language & Multiple Oldowan site endocasts & $\begin{array}{c}\text { Endocasts support claim that } \\
\text { Homo habilis had some form of } \\
\text { spoken language }\end{array}$ \\
\hline Pigment use & BK, Upper Bed II, ca. 1.48 Ma, \\
Olduvai Gorge, Dev. & $\begin{array}{c}\text { Two (2) lumps of non-local } \\
\text { "red ochre", but reanalyzed as } \\
\text { local red volcanic tuff } \\
\text { (no evidence of use) }\end{array}$ \\
\hline
\end{tabular}

Foremost among the listed objects is the grooved and pecked cobble from Olduvai Gorge, FLK North-1 site, Upper Bed I, dated $\sim 1.80$ mya (immediately below Tuff $1 \mathrm{~F}, 1.803 \pm 0.002 \mathrm{Ma}$ and above Ng’eju Tuff, $1.818 \pm 0.006 \mathrm{Ma}$ ) (Deino 2012) [25], Classic Oldowan, reported and described by Mary Leakey (1971: 84, 269, plate 18) [59] (Figure 1).

Figure 1. Grooved and pecked cobble, FLK North-1, Olduvai Gorge, 1.8 million years ago (reproduced with permission from Cambridge University Press, Mary Leakey 1971).

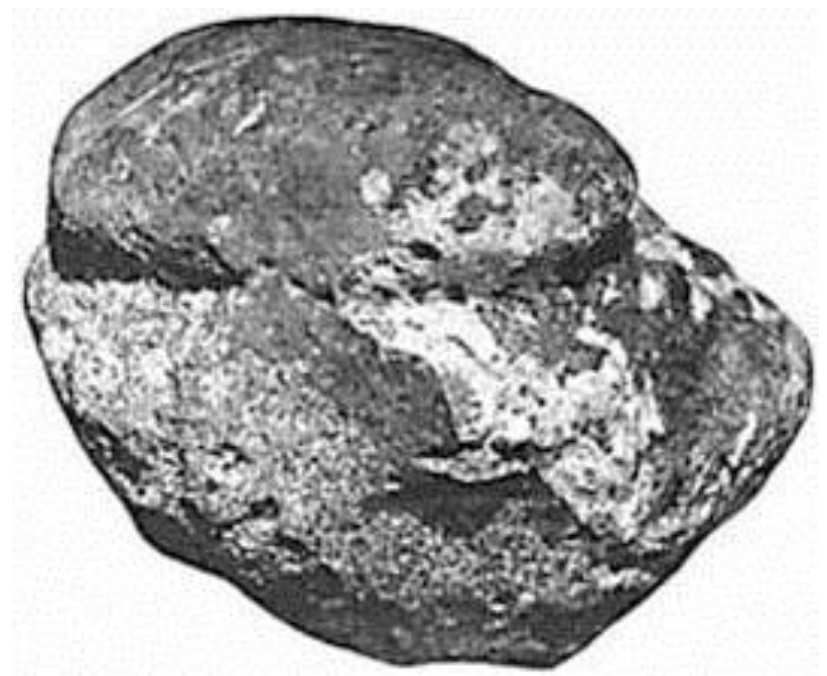

As well as being an archaeologist, Mary Leakey was an accomplished archeological illustrator. She provides (84) a detailed visual analysis of the artifact. It is a phonolite cobblestone $(79 \times 54 \times 49 \mathrm{~mm})$ with almost the entire original cortex removed by pecking and battering. Its form is oblong, the base and one side flat, the upper surface and opposite side convex; one end blunt, the opposite end obliquely pointed. On its upper surface an artificial, well-marked groove varies from 9 to $18 \mathrm{~mm}$ in depth and encircles a raised oval area, measuring $60 \times 41 \mathrm{~mm}$, which is pecked over its entire surface. The groove is continuous except for an area $20 \mathrm{~mm}$ wide, which subsequently scaled off, and a $9 \mathrm{~mm}$ wide area on the opposite side where part of the cortex remains. "There is no evidence of wear inside the 
groove" and an experiment has shown that it is sufficiently deep to hold a thong or string in position if tied round the stone at this point. On a convex side below this groove, there is a diagonal "line of four symmetrical indentations 3-4 mm in diameter, either circular or oval in shape, and measuring $0.5 \mathrm{~mm}$ in depth, together with two adjacent pitted indentations which are both larger and shallower." Battering and pitting occur on other parts of the surface, with "several irregular shallow depressions," apparently the result of wear. Leakey does not specify the weight of this artifact. Leakey states that she offers no explanation for the groove or line of peck marks; similar artifacts are not known from other Oldowan assemblages.

Emphasizing the importance of this artifact, Leakey gives an additional comment (269), noting, "this stone has unquestionably been artificially shaped, but it seems unlikely that it could have served as a tool or for any practical purpose." She compares it to the Makapansgat "pebble of many faces", noting that the Olduvai stone is not so obvious and "a great deal of imagination is required to see any pattern or significance in the form." She does observe that "with oblique lighting, however, there is a suggestion of an elongate, baboon-like muzzle with faint indications of a mouth and nostrils" and the pecked groove corresponds to what would be the base of the hairline. She notes that the Olduvai stone's pecked groove "probably by no more than a coincidence" is in a similar position to the natural groove on the Makapansgat stone. Such a figurative interpretation "is open to question, but nevertheless the occurrence of such stones at hominid sites in such remote periods is of considerable interest."

Leakey's observations were made over 50 years ago and subsequently were mentioned in articles on Lower Paleolithic non-utilitarian and potentially symbolic behavior by Ashley Montagu (1976) [71] and Stephen Edwards (1978) [29], but have not been further examined. In current debates about the emergence of hominin symbolic behavior, this artifact remains undiscussed, except for Bednarik (2013) [17], who suggests that the percussion depressions on the artifact may be utilitarian, related to nutcracking and possibly even made by chimpanzees or other primates and notes that secure identification of cupules requires considerable relevant experience. The artifact's dimensions are hand-size, and thus the size of both Oldowan anvils and hammers, but the diagonal of six indentations is incompatible with typical pit placement on either anvils or hammers. The FLK North cobble needs to be weighed and other dimensions re-measured for comparison to other Oldowan and Acheulian, chimpanzee and capuchin pitted hammers and anvils. Setting aside the speculative question of figuration, if this artifact could be re-examined and confirmed as non-utilitarian; not an accidental byproduct of failed toolmaking or of battering activities; and the markings even partially intentional, it might be categorized as a petroglyph, combining both geometric shapes and glyph-like motifs.

Another strong candidate for Oldowan symbolic behavior from Olduvai Gorge, MNK Main, upper Middle Bed II, between Tuffs IIB and IIC, 1.5-1.6 Ma (Mora 2005) [72], Developed Oldowan B reclassed as Early Acheulian, is a $6.6 \mathrm{~kg}$ (14.5 lb.) "subspheroid", varying 13 to $16 \mathrm{~cm}$ in diameter, noted as the largest of twelve massive specimens among 143 subspheroids, which are mostly quartz and quartzite as well as two gneiss, eight lava and one pegmatite (Leakey 1971:153, plate 21) [59] (Figure 2). Leakey does not specify the material of this artifact. 
Figure 2. Subspheroid with apparent dot-and-undulating-line motif framed in hexagon shape, MNK Main, Olduvai Gorge, around 1.5 million years ago (reproduced with permission from Cambridge University Press, Mary Leakey 1971).

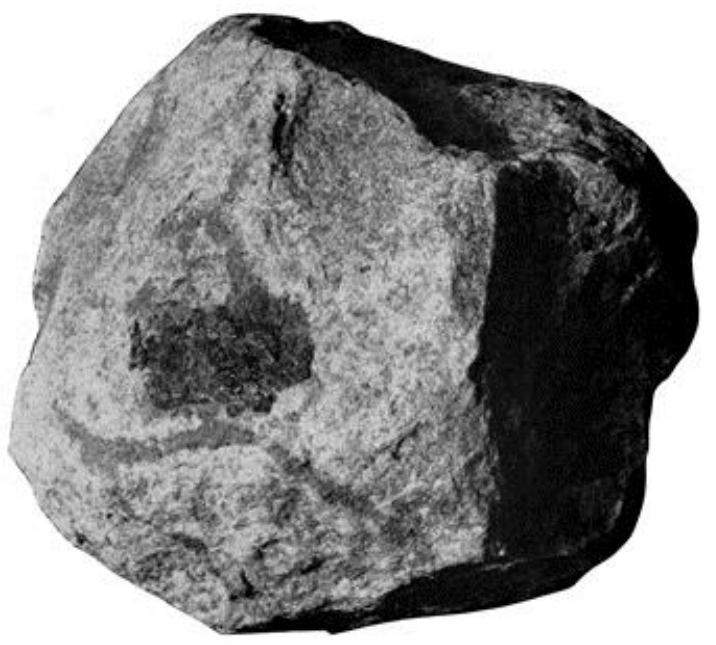

The mineralogy of this artifact needs identification and its lithic classification reconsidered based on more recent studies critiquing Leakey's "subspheroid" category (Mora 2005; de la Torre 2009-2010) [72,85]. In addition to its unusual weight and size dimensions, I observe that it has on its surface apparent natural markings, a dot and an undulating line. These marks need to be re-examined to determine to what extent they are natural, the result of intact or eroded mineral inclusion or some sort of applied pigment. The marks appear framed by the hexagonal shape around the circumference of the object. Research is needed to determine if the hexagon shape is natural, the accidental by-product of battering or the result of intentionally removing six flakes, thus forming the hexagonal shape, or some combination of these alternatives. If verified as non-utilitarian, intentional working of the stone, this would be a second example of Oldowan palaeoart, a geometric artifact with a glyph-like motif, and the pattern of marking motifs could be compared to the "cupule and undulating line" petroglyph made from the Acheulian or Oldowan level in Auditorium Cave, Bhimbetka, India, noted above.

A re-examination of this MNK artifact should include comparison to at least two other Olduvai "anvils" that have hexagonal shape. Leakey (1971: 86, no illustration) [59] reported an anvil, hexagonal block of quartzite, edges approximate $90^{\circ}$, showing crushing and chipping $(93 \times 89 \times 72$ mm, mean $84 \mathrm{~mm}$.) at FLK North Clay with Root Casts, Lower Bed II, between Tuffs IIA, $1.74 \pm 0.3$ Ma, and 1F, $1.803 \pm 0.002 \mathrm{Ma}$ ) (Stanistreet 2012; Ashley 2007; Deino 2012) [1,25,80], and a second anvil hexagonal block of hornblende gneiss, with battering and crushing on edges from FLK North Sandy Conglomerate 6, lower Middle Bed II (1971: 107, no illustration), between Tuffs IIB and IIA, 1.6-1.66 or 1.74 Ma (Mora 2005; Stanistreet 2012; Ashley 2007) [1,69,77], Developed Oldowan A. Careful examination is needed to determine whether the hexagonal shape of these two artifacts is intentional flaking, the accidental result of utilitarian percussive battering activities or simply the original shape of natural blocks. If intentional flaking were established along with that of the subspheroid above, this context would seem to suggest that the hexagonal geometric shape, circumstantial as the evidence is, might be categorizable as a "geometric shaped artifact" and as a "decorated tool", the possible alternative symbolizations of such open for further debate. 
An Oldowan site at Koobi Fora, northeastern Lake Turkana, Kenya, FxJj1, in the KBS Tuff dated at $1.869 \pm 0.021 \mathrm{Ma}$ (Lepre and Kent 2010) [60], Classic Oldowan, has yielded a curious artifact, \#302, which I have called the "rhomboid-in-a-core" (Harrod 1992, Figure 1) [47] (Figure 3). Staff at the Koobi Fora Field School in 1990 pointed to a cast of this artifact displayed at the Koobi Fora Museum when I asked where the "art" was, and I photographed it, as well as the original, at the National Museum in Nairobi.

Figure 3. Four core choppers, FxJj1, Koobi Fora, around 1.9 million years ago. Top-right, "broken core" with rhomboid shape after four cortical flake removals (photo James Harrod, courtesy National Museums of Kenya).

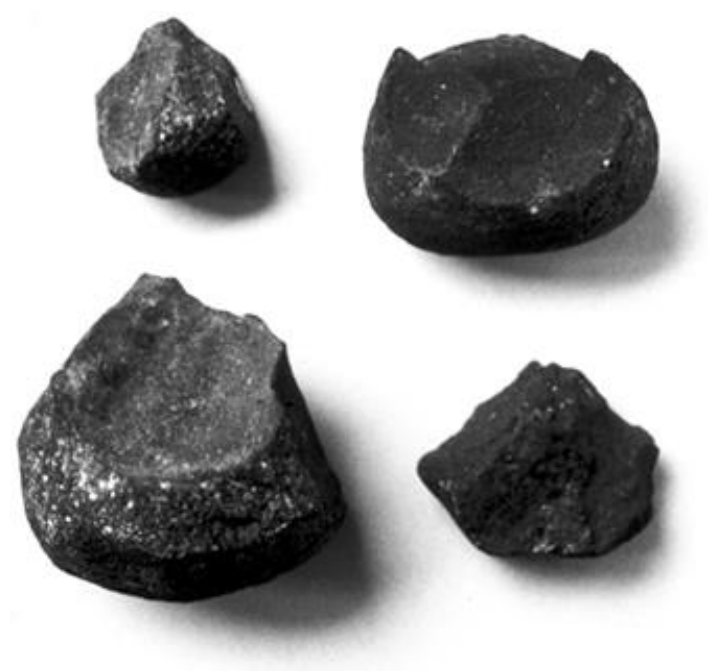

This artifact was classified as a "broken/irregular chopper" on a basalt pebble. The Koobi Fora Museum cast of the core shows more clearly the symmetrical rhomboid shape that emerged "inside" the core following four bifacial flake removals (Figure 4).

Figure 4. Cast of the broken core with rhomboid shape after four cortical flake removals. The horizontal crack in the rhomboid is caused by the split sides of the cast. FxJj1, Koobi Fora, around 1.9 million years ago (photo James Harrod, courtesy National Museums of Kenya).
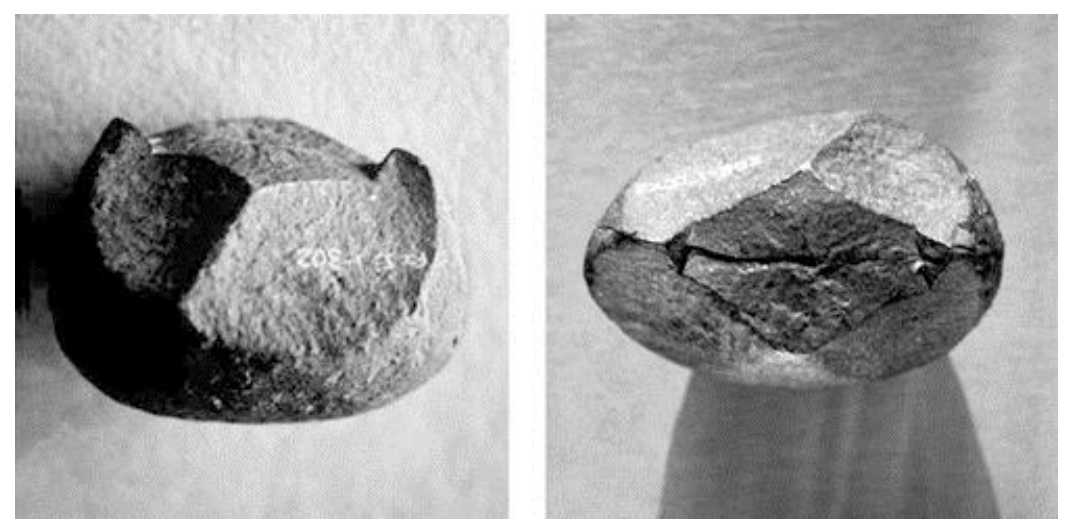
All the lava used for tools at the site, was transported into the site from several kilometers away (Isaac 1976; Isaac et al. 1976; no illustration) [54,55]. Toth (1987) [86] conducted stone tool flaking replication experiments to determine typical stages of Oldowan lithic reduction, which at any site might be used to identify stages performed "on-site" and "off-site". Toth identified six stages of reduction and their flake types (I-VI) ranging with type I (cortical platform, totally cortical dorsal surface to type VI (non-cortical platform, totally non-cortical dorsal surface) and then conducted simulations. Toth simulated six FxJj sites, with only FxJj50 having actual and simulated distributions roughly similar, and thus the early stages of reduction at the other five were arguably done off-site. Toth ruled out various alternative explanations for such discrepancies, arriving at the explanation that initial flaking was done off-site, presumably at distant lava source locations.

In the case of FxJj1, simulation prediction of flake type distribution (22\% types I-III and 78\% types IV-VI) was starkly contrasted with actual types at the site (4\% type II, 96\% type VI; or out of 23 total flakes, 2 type V flakes, 20 type VI flakes and only 1 type I flake). Thus, with the exception of one flake, all flaking at FxJj1 appears to have been late stage V or VI. Considering Toth's typology, "broken core" \#302 appears to evidence for Type I or Type 2 flake removals, indicating flaking off-site at the distant lava source. This early stage flaking would have generated accidentally the inner symmetric rhomboid shape on a cleavage plane. Rather than discard the stone at this point as useless either for making a chopper or for making more flakes, it was manuported to FxJj1. It shows no evidence of use as a percussor. Why was this broken useless core manuported several kilometers to the occupation site? I suggest that it was because of its inherent "aesthetic" interest, and I suggest that it be categorized as a combination of symbolic behaviors: curation of an exotic object, geometric artifact, and an exotic or accidentally decorated "tool". Harrod (1992) [47] proposed an extended reconstruction of the possible symbolism of this artifact.

Though perhaps less probable as symbolic behavior, Leakey (1971) [59] identified two exotic anvil stones from Olduvai Gorge (Figure 5). One from FLK North 1, Upper Bed I, 1.80 Ma, Classic Oldowan, is described as a "pitted anvil", conical block, vesicular basalt, dia. 9-10 cm, pecked pit $29 \times 17 \mathrm{~mm}$, depth $9 \mathrm{~mm}$ (p. 81, plate 17-bottom). A second is from FLK North Sandy Conglomerate, lower Middle Bed II, between Tuffs IIB and IIA, 1.6-1.66 or 1.74 Ma (Mora 2005; Stanistreet 2012; Ashley 2007) $[1,72,80]$, with tools classed as Developed Oldowan A, and described as "unusual anvil", a subspherical lava cobblestone with three areas of circumference pitted and battered, with pit $35 \times 24$ $\mathrm{mm}$, depth $5 \mathrm{~mm}$ in center of one face (p. 114, plate 17-top). Based on Leakey's descriptions, I suggest that in Plate 17 the photos are reversed, since deeper pitting appears on the top photo, which thus would be the anvil from FLK North, and I have so titled them in Figure 5.

Bednarik notes these images show apparent cupules but suggests they may be utilitarian or similar to stone hammers used by chimpanzees (2008; 2003) [11,16] and similarly Goren-Inbar et al. (2002) [45] suggested these anvils appear similar to anvils at Gesher Benot Ya'aqov, associated with nutcracking. Recently de la Torre et al. (2009-2010) [85] asserts that the anvil with deep pit "is dubious and we believe it is difficult to support that such pits are human made instead of natural." These anvils and especially the FLK North anvil with deep and centered pit evoking interior and exterior concentric circle shapes need to be re-examined to rule in or out these alternatives: (a) natural deep indentation; (b) hominin pitted anvil or hammerstone with normal utilization wear; (c) chimpanzee pitted anvil or hammerstone with normal utilization wear; (d) a utilization pit intentionally enhanced 
by percussion to yield an "exaggerated pit". If the second and fourth alternatives were supported, the artifact would constitute a "cupule" petroglyph and also might be classed as an exotic tool.

Figure 5. Unusual pitted anvils, (top) FLK North-1, Olduvai Gorge, 1.8 million years ago. (bottom) FLK North Sandy Conglomerate, Bed II, around 1.6 million years ago (reproduced with permission from Cambridge University Press, Mary Leakey 1971).

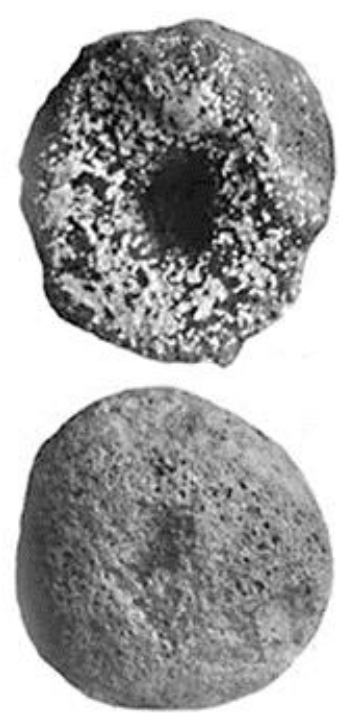

Although the identified hominin has recently come under question, cutmarks on a bone from South Africa evidence possible symbolic behavior: Sterkfontein M5A, 1.40-1.78 Ma (Herries and Shaw 2011) [53], Stw53 Homo habilis (Curnoe and Tobias 2006; but perhaps Au. africanus, Berger et al. 2010) $[19,23]$. This maxilla with stone tool cutmarks, presumably used to remove the mandible from the cranium, whether cannibalism, curation, mutilation and/or funerary procedure, provides the earliest evidence of post-mortem manipulation of hominid carcass by other hominids (Pickering, White and Toth 2000) [77]. The Stw53 evidence is more ambiguous with regards the explanation rather than occurrences of cutmarks, scrape marks and juvenile polishing on each of three later skulls, suggesting it was not used for food consumption but intentional postmortem defleshing (Clark et al. 2003) [21], Bodo erectus or heidelbergensis, 600 ka (White 1986; Clark et al. 1994) [22,88]; Kabwe, rhodesiensis or heidelbergensis, dating uncertain with range 130-300 (Barham et al. 2002) [2] or $>780 \mathrm{ka}$ (McBrearty and Brooks 2000) [70]; and Herto sapiens idaltu, 160 ka (White et al. 2003) [89]. With respect to Homo sapiens sapiens there is an extensive literature on postmortem defleshing as a mortuary and thus symbolic practice. In general with respect to the function of habiline skull cutmarks, I suggest that the ambiguity of the explanatory alternatives suggested by Pickering, White and Toth might be expected since it is unlikely that a functional differentiation into their four alternatives would apply at such an early stage of evolution. More likely would be a blend of two or more of these functions. Discovery of more occurrences of Oldowan hominin bone cutmarks might further clarify function, but the mere ambiguity of function does not rule out symbolic behavior or its interpretation.

While the evidence is circumstantial, paleoneurology endocasts support the claim that Homo habilis had some form of spoken language (Tobias 2005, first proposed 1979; Tobias 1991, 1987; Falk 2007, 2004, 1983; Falk et al. 2000) [30-33,82-84]. While there is an extensive speculation about the 
possibility of habiline "proto-language", my review indicates that only one linguist has attempted to reconstruct Oldowan language, namely the "phememe" theory of Mary LeCron Foster (1996) [37].

Finally, a claim for possible Oldowan pigment use at Olduvai Gorge seems unsupported. At BK, Upper Bed II, around 1.48 Ma (Mora 2005) [72], classed as Developed Oldowan B (or might be an Early Acheulian bipolar technique assemblage), Louis Leakey reported two lumps of non-local red ochre (Leakey 1958:1100; cited Hay 1976:185) [51,58]. This has been reanalyzed as red volcanic tuff, possibly used as ochre (Oakley 1981:207) [74]. However, this red tuff is local to the site (R. Hay, letter to author, 6 November 1998) It has not been analyzed for pigment use striations. Its significance remains uncertain (Bednarik 2003:10) [11].

\section{Discussion}

Considering the seven stone artifacts from the Oldowan of Olduvai Gorge and Koobi Fora, the strongest candidates for palaeoart, in chronological order, appear to be the FxJj1 "broken core" with inner rhomboid shape, 1.87 million years ago, the FLK North grooved and pecked cobble, $\sim 1.80$ million years ago, and the MNK Main subspheroid, 1.5-1.6 million years ago.

The FxJj1 "rhomboid-in-a-core" is clearly a manuport and, based on Toth's actualist studies, the inference that it was manuported in its broken state, and hence non-utilitarian, is not unlikely. Though the evidence is only circumstantial; based on that evidence, this artifact, which is hominin-made, albeit an accidental by-product, appears to be the earliest instance of hominin-made palaeoart. It may be categorized as a combination of symbolic behaviors: curation of an exotic object, geometric artifact, and an exotic or accidentally "decorated tool". Acknowledging the circumstantiality of the evidence, Harrod $(2013,2010,1992)[47,49,50]$ proposed an interpretation of the "aesthetics" of this artifact as an example of the "first metaphor", a cognitive analogical metaphor having the formula “nutmeat $+:$ shell - :: core - : flakes +", as well as its reversal (or anti-metaphor), "nutmeat + : shell $\because$ core + : flakes -", which might be paraphrased as an awareness of the "core-pith-seed-sustenanceessence." Combined with a geometric shape, as in this "core-with-inner-rhomboid" case, it yields a concept of a "geometric-core-essence". To what extent this latter characterization is a projection of our sapiens conceptual evolution, I leave for future hermeneutical reflections.

If the FLK North grooved and pecked cobble could be re-examined and confirmed as non-utilitarian and the markings to one degree or another intentional, this would be the earliest evidence for intentional hominin-made palaeoart mark making. It might be categorized as the earliest petroglyph, one that combines both geometric shapes and glyph-like motifs. Further, the apparent two sets of four and two incised dots ("cupules"), if confirmed to have been intentional, could be interpreted as the earliest evidence of symbolic representation of numerosity (comparison of arithmetic sets and larger and smaller size shapes) in human evolution. While acknowledging the need for re-confirmation of working traces on this object, I have suggested hypotheses and a method for an art-theoretic interpretation of the design principles applied by the Oldowan hominin, based on design principles in Macnab (2012) [61] cross-mapped onto brain imaging studies of art-making and paleoneurology endocast studies of the evolving habiline brain (Harrod 2013) [50]. 
The third strong candidate for Oldowan symbolic behavior is the MNK Main subspheroid with what appears in the photo to be a composition, dot-and-undulating-line-in-a-hexagon. If intentional working of the hexagonal shape and dot-and-line motif could be rigorously verified, this artifact would be a second example of Oldowan palaeoart, one that combines an artificially made framing geometric shape containing an apparently natural glyph-like motif. This glyph-like dot-and-undulating-line motif is similar to both the FLK North grooved and pecked cobble with its line and dot motifs and the intentionally engraved cupule-and-meandering-line petroglyph at Auditorium Cave, Bhimbetka, India, noted earlier. Harrod (2007) [48] interpreted the Bhimbetka glyph from a design perspective and compared it to Kandinsky's analysis of a similar motif in Point and Line to Plane (1979: Figure 1) [56]. Reflecting on artmaking in human child development, Matthews (1994) [67] identifies one typical toddler artmaking schema as "beginnings and ends of lines (demarcated or not)", which subsequently in early childhood occurs in the "trajectory-and-impact" schema, and Mathews observes the same artmaking schemas emerge in captive chimpanzees (2011) [69]. There is a remarkable similarity between the art and play products of these Matthews schemas and the line-and-dot motifs in the FLK North grooved and pecked cobble, the MNK Main subspheroid and the Bhimbetka petroglyph.

Interestingly, if the three strongest candidates for Oldowan symbolic behavior - the FLK North grooved and pecked ovoid cobble, the MNK hexagon with line-and-dot markings and the Koobi Fora core-with-inner-rhomboid-were to be verified, this would infer a habiline "aesthetic" interest in geometric crystal-like shapes. Future research at Olduvai Gorge and Koobi Fora might determine if fossils or crystal spars, e.g., calcite or quartz, would have been observable in the environments around these sites and served as models for geometric crystal-shapes in Oldowan symbolic behavior.

If we want to say anything about these artifacts and their possible symbolic significance, what method or criteria can we develop to reduce the degree of projecting our own cultural and species bias onto them? In terms of art history method, I suggest first a careful visual analysis of techniques used and description of aesthetic features of the object (loci of viewer's gaze and their sequence; shapes, lines, marks, patterns, use of space, tensions, medium, texture, color, light and shadow, etc.), followed by interpretation of utilitarian/non-utilitarian features and functions, identification of symbolic behavior category, and hypotheses about "meaning" constrained by preceding analyses.

For identifying interpretive steps to reduce projection, I have proposed analytical procedures and criteria that can be used to reconstruct an Oldowan habiline design competence (Harrod 2013) [50]. First, I proposed four basic Oldowan work techniques (body techniques or elementary actions on matter), including cutting with sharp edge, pounding with hammer or chopper, piercing with sharp instrument, and curving-around-and-linking (as in probable sleep-nest-making and possible string making). Then I identified a list of nineteen graphic design principles based on Macnab (2012) [61], such as gestalt structure principles, shape degrees of freedom, visual language, glyph, patterns of movement, rotational and translational symmetry, axial and locative image schemas, structural forms of flow, and agency-imprint. I suggest that graphic design theory may be used as an excellent bridge between art-design and tool-design ("art" and "science"). I then crosschecked the list of design principles for their possible neural substrates in neuroscience brain-imaging studies of contemporary Homo sapiens sapiens making stone tools, calligraphy and art. I further crosschecked the design principle neural substrates against paleontology endocasts of the Homo habilis brain to delete those neural substrates (and corresponding design principles) that did not emerge until Homo erectus and the 
Acheulian tool industries. This method of analysis using graphic design criteria can be applied to either Oldowan tools or non-utilitarian artifacts. Results of applying this method to interpret the putative FLK North grooved and pecked cobble and other Oldowan artifacts I shall leave for a future discussion, pending a scientific re-examination of proposed Oldowan artifacts to determine if they actually are or are not classifiable as symbolic behavior.

\section{Implications}

If the FLK North grooved and pecked cobble petroglyph, $\sim 1.80$ million years ago, or the MNK Main subspheroid, hexagonal with markings, 1.5-1.6 million years ago, as well as the FxJj1 "corewith-inner-rhomboid-shape", $\sim 1.87$ million years ago, were to be verified according to current scientific standards, this would put the date of the earliest known examples of human palaeoart symbolic marking behavior at around 1.8 million years ago, a critical shift point in human evolution. This would be around a million years earlier than current proposals for the earliest palaeoart. It would demonstrate that Homo habilis/rudolfensis or a very early Homo erectus had substantially more advanced cognitive, design and symbolic competencies than suggested in current theories, and it would constitute a challenge to develop more advanced cognitive semiotic and art-theoretic analytical tools for illuminating the role of such palaeoart in hominin cultural evolution.

\section{Limitations}

This is a review of literature focused on African Oldowan archaeological sites. There is no guarantee that it has not overlooked additional proposed candidates from dated African Oldowan sites or studies with scientific support or objections to these artifacts. The author welcomes such references.

Mary Leakey's (1971) [59] observations were made over 50 years ago, and have not had further scientific analysis. They are long overdue for re-examination. To advance research on Oldowan palaeoart and other symbolic behaviors on a scientific basis, each of the six Olduvai Gorge artifacts needs to be visually and microscopically re-examined to determine working traces and to what extent apparent marking features are natural, natural but artificially enhanced and/or fully artificial. This requires establishing each artifact's chaîne-opératoire including reduction sequences, especially with respect to such techniques as pounding off a cortex, "framing" natural or artificial markings, grooving, and pecking indentations ("cupules"). Additionally, CT scans to assess exfoliation, fracture plains, erosion, etc., use-wear or residue analysis might help determine natural, utilitarian and non-utilitarian aspects of these artifacts, especially with respect to possible suspension "thong" in the FLK North-1 grooved and pecked cobble and the anvils with unusual or exaggerated pits. Once more precise details of workmanship are established one can reconstruct the artifact's cognitive, design and other semiotic features on a more solid basis.

An additional limitation on research is that this Oldowan literature review has identified only seven putative symbolic artifacts. This infrequency might be explained by taphonomic loss, inadequate search or actual rarity. If even one of the proposed candidates for palaeoart could be verified, one might easily imagine there are many more, even hundreds of other occurrences in the million years of the Oldowan and other chopping tool traditions across Africa and Eurasia. This prospect would challenge Oldowan archaeologists to re-examine stored collections and carefully examine newly 
excavated stone and bone assemblages for objects which might evidence symbolic behavior. How many artifacts classed as "atypical tools", "broken" or "waste" actually might be occurrences of non-utilitarian symbolic behavior that could be added to the Oldowan symbolic behavior corpus?

\section{Conclusions}

This literature review has identified eight potential candidates for Oldowan palaeoart, seven in stone and one in bone. Among the stone artifacts the strongest candidates for palaeoart, in chronological order, appear to be the Koobi Fora FxJj1 "broken core" with inner rhomboid shape, 1.87 million years ago, the Olduvai Gorge FLK North grooved and pecked cobble, $\sim 1.80$ million years ago, and MNK Main subspheroid with apparent "line-and-dot" motif, 1.5-1.6 million years ago. Given its position in typical Oldowan stone tool reduction stages, the artifact from Koobi Fora seems to be supported as a manuported and curated "accidental" exotic object and also a non-utilitarian artifact bearing a geometric shape. If the FLK North-1 grooved and pecked cobble or the other five Olduvai Gorge candidates could be more scientifically verified as examples of even partially intentional non-utilitarian marking behavior, this would be a paradigm shift in our understanding of the emergence and evolution of culture during the Oldowan, including "symbolic behavior", "palaeoart", "religious" ritual, numerosity, and language. Scientific and interpretive re-examination of these Olduvai Gorge candidates for Oldowan palaeoart is critical.

\section{Acknowledgments}

I thank the field staff of Koobi Fora Field School 1990 for pointing to the FxJj1 "rhomboid-core" artifact as a possible example of Oldowan "art", and the National Museums of Kenya for the opportunity to photograph the cast at Koobi Fora and its original in Nairobi. I thank Cambridge University Press for permission to reproduce images from Leakey 1971. I also thank the peer reviewers for their excellent suggestions to improve this review.

\section{Conflicts of Interest}

The author declares no conflict of interest.

\section{References}

1. Ashley, G.M. Orbital rhythms, monsoons, and playa lake response, Olduvai Basin, equatorial East Africa (ca. 1.85-1.74 Ma). Geology 2007, 35, 1091-1094.

2. Barham, L.S.; Pinto Llona, A.C.; Stringer, C.B. Bone tools from Broken Hill (Kabwe) cave, Zambia, and their evolutionary significance. Before Farming 2002, 2, 1-12.

3. Beaumont, P.U.B.; Bednarik, R.G. Tracing the emergence of palaeoart in Sub-Saharan Africa. Rock Art Res. 2013, 30, 33-54.

4. Bednarik, R.G. An Acheulian hematite pebble with striations. Rock Art Res. 1990, 7, 75.

5. Bednarik, R.G. Concept-mediated marking in the Lower Paleolithic. Curr. Anthropol. 1995, 36, 605-634. 
6. Bednarik, R.G. The cupules on Chief's Rock, Auditorium Cave, Bhimbetka. Artefact 1996, 19, 63-72.

7. Bednarik, R.G. The role of Pleistocene beads in documenting hominid cognition. Rock Art Res. 1997, 14, 27-41.

8. Bednarik, R.G. The 'Australopithecine' cobble from Makapansgat, South Africa. South Archaeol. Bull. 1998, 53, 4-8.

9. Bednarik, R.G. An Acheulian figurine from Morocco. Rock Art Res. 2001, 18, 115-116.

10. Bednarik, R.G. An Acheulian palaeoart manuport from Morocco. Rock Art Res. 2002, 19, 137-139.

11. Bednarik, R.G. The earliest evidence of palaeoart (with comments). Rock Art Res. 2003, 20, 89-135.

12. Bednarik, R.G. A figurine from the African Acheulian. Curr. Anthropol. 2003, 44, 405-413.

13. Bednarik, R.G. IFRAO Rock Art Glossary, 2003. Available online: http://home.vicnet.net.au/ auranet/glossar/web/glossary.html (accessed on 5 May 2013).

14. Bednarik, R.G.; Kumar, G.; Watchman, A.; Roberts, R.G. Preliminary results of the EPI Project. Rock Art Res. 2005, 22, 147-197.

15. Bednarik, R.G.; Kumar, G.; Watchman, A.; Roberts, R.G. Response to Harrod's questions. Rock Art Res. 2006, 23, 114-118.

16. Bednarik, R.G. Cupules. Rock Art Res. 2008, 25, 61-100.

17. Bednarik, R.G. Pleistocene palaeoart of Africa. Arts 2013, 2, 6-34.

18. Bednarik, R.G. Pleistocene Palaeoart of Asia. Arts 2013, 2, 46-76.

19. Berger, L.R.; de Ruiter, D.J.; Churchill, S.E.; Schmid, P.; Carlson, K.J.; Dirks, P.H.G.M.; Kibbi, J.M. Australopithecus sediba: A New Species of Homo-Like Australopith from South Africa. Science 2010, 328, 195-204.

20. Carbonell, E.; Mosquera, M.; Ollé, A.; Rodriguez, X.P.; Sala, R.; Vergès, J. M.; Arsuaga, J.L.; Bermudez de Castro, J.M. Les premiers comportements funéraires auraient-ils pris place à Atapuerca, il y a 350000 ans? Did the earliest mortuary practices take place more than 350000 years ago at Atapuerca? L'Anthropologie 2003, 107, 1-14.

21. Clark, J.D.; Beyene, Y.; WoldeGabriel, G.; Hart, W.K.; Renne, P.R.; Gilbert, H.; Defleur, A.; Suwa, G.; Katoh, S.; Ludwig, K.R.; et al. Stratigraphic, chronological and behavioural contexts of Pleistocene Homo sapiens from Middle Awash, Ethiopia. Nature 2003, 423, 747-752.

22. Clark, J.D.; Heinzelin, J.; Schick, K.D.; Hart, W.K.; White, T.D.; WoldeGabriel, G.; Walter, R.C.; Suwa, G.; Asfaw, B.; Vrba, E.; et al. African Homo erectus: Old radiometric ages and young Oldowan assemblages in the Middle Awash Valley, Ethiopia. Science 1994, 264, 1907-1910.

23. Curnoe, D.; Tobias, P.V. Description, new reconstruction, comparative anatomy, and classification of the Sterkfontein Stw 53 cranium, with discussions about the taxonomy of other southern African early Homo remains. J. Hum. Evol. 2006, 50, 36-77.

24. Dart, R. The waterworn Australopithecine pebble of many faces from Makapansgat. S. Afr. J. Sci. 1974, 70, 167-169.

25. Deino, A. 40Ar/39Ar dating of Bed I, Olduvai Gorge, Tanzania, and the chronology of early Pleistocene climate change. J. Hum. Evol. 2012, 63, 251-273. 
26. D’Errico, F.; Gaillard, C.; Misra, V.N. Collection of Non-Utilitarian Objects by Homo Erectus in India. Hominidae. In Proceedings of the 2nd International Congress of Human Paleontology, 1989; Editoriale Jaca Book: Milan, Italy, 1989; pp. 237-239.

27. D'Errico, F.; Nowell, A. A new look at the Berekhat Ram figurine: Implications for the origins of symbolism. Camb. Archaeol. J. 2000, 10, 123-167.

28. Despriée, J.; Voinchet, P.; Gageonnet, R.; Dépont, J.; Bahain, J-J.; Falguères, C.; Tissoux, H.; Dolo, J-M.; Courcimault, G. Les vagues de peuplements humains au Pléistocène inférieur et moyen dans le bassin de la Loire moyenne, région Centre, France. Apports de l'étude des formations fluviatiles. L'anthropologie 2009, 113, 125-167.

29. Edwards, S.W. Nonutilitarian activities in the lower Paleolithic: A look at the two kinds of evidence. Curr. Anthropol. 1978, 19, 135-137.

30. Falk, D. Cerebral cortices of East African early hominids. Science 1983, 221, 1072-1074.

31. Falk, D. Prelinguistic evolution in early hominins: Whence motherese? Behav. Brain Sci. 2004, 27, 491-503.

32. Falk, D. The Evolution of Broca's Area, IBRO History of Neuroscience, 2007. Available online: http://ibro.info/wp-content/uploads/2012/12/The-Evolution-of-Brocas-Area.pdf (accessed on 5 September 2013).

33. Falk, D.; Redmond, J.C.; Guyer, J.; Conroy, G.C.; Recheis, W.; Weber, G.W.; Seidler, H. Early hominid brain evolution: A new look at old endocasts. J. Hum. Evol. 2000, 38, 695-717.

34. Feliks, J. The impact of fossils on the development of visual representation. Rock Art Res. 1998, $15,109-124$.

35. Feliks, J. Musings on the Palaeolithic Fan Motif. In Exploring the Mind of Ancient Man: Festschrift to Robert G. Bednarik; Reddy, P.C., Ed.; Research India Press: New Delhi, India, 2006; pp. 249-266.

36. Feliks, J. Phi in the Acheulian: Lower Palaeolithic Intuition and the Natural Origins of Analogy. In Pleistocene Palaeoart of the World; Bednarik, R.G., Hodgson, D., Eds.; British Archaeological Reports: Oxford, UK, 2008; Volume 19, BAR International Series 1804, pp. 11-31.

37. Foster, M.L. The Reconstruction of the Evolution of Human Spoken Language. In Handbook of Human Symbolic Evolution; Lock, A., Peters, C., Eds.; Clarendon: Oxford, UK, 1996; pp. 747-775.

38. Gaillard, C.; Mishra, S.; Singh, M.; Deo, S.; Abbas, R. Lower and Early Middle Pleistocene Acheulian in the Indian sub-continent. Quat. Int. 2010, 223-224, 234-241.

39. Gaillard, C.; Raju, D.R.; Misra, V.N.; Rajaguru, S.N. Acheulian occupation at Singi Talav in the Thar desert: A preliminary report on 1982 excavation. Man Environ. 1983, 7, 112.

40. Goren-Inbar, N. A figurine from the Acheulian site of Berekhat Ram. Mitekufat Haeven 1986, 19, $7-12$.

41. Goren-Inbar, N. Additional remarks on the Berekhat Ram figurine. Rock Art Res. 1995, 12, 131-132.

42. Goren-Inbar, N.; Feibel, C.S.; Verosub, K.L.; Melamed, Y.; Kislev, M.E.; Tchernov, E.; Saragusti, I. Pleistocene milestones on the out-of-Africa corridor at Gesher Benot Ya'aqov, Israel. Science 2000, 289, 944-947.

43. Goren-Inbar, N.; Lewy, Z.; Kislev, M.E. Bead-like fossils from an Acheulian occupation site, Israel. Rock Art Res. 1991, 8, 133-135. 
44. Goren-Inbar, N.; Sharon, G. Axe Age: Acheulian Tool-Making from Quarry to Discard; Equinox: London, UK, 2006.

45. Goren-Inbar, N.; Sharon, G.; Melamed, Y.; Kislev, M. Nuts, nut cracking and pitted stones at Gesher Benot Ya'aqov, Israel. Proc. Natl. Acad. Sci. USA 2002, 99, 2455-2460.

46. Guadelli, A. Etude des incisions du plus ancien os grave decouvert dans la grotte Kozarnika (Bulgarie du Nord-Ouest): Une preuve de l'existence du symbolism au paléolithique inferieur. Archaeol. Bulg. 2004, 8, 1-9.

47. Harrod, J.B. Two million years ago: The origins of art and symbol. Continuum 1992, 2, 4-29.

48. Harrod, J.B. The Bhimbetka Glyphs. In Exploring the Mind of Ancient Man: Festschrift to Robert G. Bednarik; Reddy, P.C., Ed.; Research India Press: New Delhi, India, 2007; pp. 317-330.

49. Harrod, J.B. Four Memes in the Two Million Year Evolution of Symbol, Metaphor and Myth. Presented at Seminar on Comparative Mythology: Deep Reconstruction, Radcliffe Institute for Advanced Study, Harvard University, Cambridge, MA, USA, 6-7 October 2010. Available online: www.originsnet.org/Harrod IACM 2010 PPT.pdf (accessed on 5 December 2013).

50. Harrod, J.B. Symbolic Behavior (Palaeoart) at Two Million Years Ago: The Olduvai Gorge FLK North Pecked Cobble-The Earliest Artwork in Human Evolution. Presented at Archaeology and the Science of Rock Art Session, IFRAO International Rock Art Congress 2013, Albuquerque, NM, USA, 26-31 May 2013. Available online: http://www.originsnet.org/Harrod Olduvai 22 slides IFRAO 2013.pdf (accessed on 5 December 2013).

51. Hay, R.L. Geology of the Olduvai Gorge: A Study of Sedimentation in a Semiarid Basin; University of California Press: Berkeley, CA, USA, 1976.

52. Herries, A.I.R.; Pickering, R.; Adams, J.W.; Curnoe, D.; Warr, G.; Latham, A.G.; Shaw, J. A multi-disciplinary perspective on the age of Australopithecus in Southern Africa. In The Paleobiology of Australopithecus. Vertebrate Paleobiology and Paleoanthropology; Reed, K.E., Fleagle, J.G., Leakey, R.E., Eds.; Springer: Dordrecht, Netherlands, 2013; pp. 21-40.

53. Herries, A.I.R.; Shaw, J. Palaeomagnetic analysis of the Sterkfontein palaeocave deposits: Implications for the age of the hominin fossils and stone tool industries. J. Hum. Evol. 2011, 60, 523-539.

54. Isaac, G.L. Plio-Pleistocene Artifact Assemblages from East Rudolf, Kenya. In Earliest Man and Environments in the Lake Rudolf Basin: Stratigraphy, Paleoecology, and Evolution; Isaac, G.L., Ed.; University of Chicago Press: Chicago, IL, USA, 1976; pp. 552-564.

55. Isaac, G.L.; Harris, J.W.K.; Crader, D. Archaeological Evidence from the Koobi Fora Formation, Kenya. In Earliest Man and Environments in the Lake Rudolf Basin: Stratigraphy, Paleoecology, and Evolution; Isaac, G.L., Ed.; University of Chicago Press: Chicago, IL, USA, 1976; pp. 533-551.

56. Kandinsky, W. Point and Line to Plane; Dover: New York, NY, USA, 1979.

57. Kumar, G. Daraki-Chattan: A palaeolithic cupule site in India. Rock Art Res. 1996, 13, 38-46.

58. Leakey, L.S.B. More Giant Animals from Olduvai; light on Chellean Man's Way of Life; and an Ivory Handaxe of Half a Million Years Ago. The Illustrated London News, 5 July 1958; pp. 41-43.

59. Leakey, M.D. Olduvai Gorge, Vol. 3: Excavations in Beds I \& II, 1960-1963; Cambridge University Press: Cambridge, UK, 1971. 
60. Lepre, C.J.; Kent, D.V. New magnetostratigraphy for the Olduvai Subchron in the Koobi Fora Formation, northwest Kenya, with implications for early Homo. Earth Planet. Sci. Lett. 2010, 290, 362-374.

61. Macnab, M. Design by Nature: Using Universal Forms and Principles in Design; New Riders: Berkeley, CA, USA, 2012.

62. Mania, D.; Mania, U. Deliberate engravings on bone artefacts of Homo erectus. Rock Art Res. 1988, 5, 91-95.

63. Marshack, A. The Berekhat Ram figurine: A late Acheulian carving from the Middle East. Antiquity 1997, 71, 327-337.

64. Matthes, W. Frühe bildende Kunst in Europa. Zeitschrift für Religions- und Geistesgeschichte 1963, $X V, 164-179$.

65. Matthes, W. Die Entdeckung der Kunst des Älteren und Mittleren Paläolithikums in Norddeutschland. Jahrbuch für Prähistorische und Ethnographische Kunst (IPEK) 1964/1965, 21, 1-18.

66. Matthes, W. Eiszeitkunst im Nordseeraum; Otterndörfer Verlags: Hamburg, Germany, 1969.

67. Matthews, J. Deep structures in children's art: Development and culture. Vis. Arts Res. 1994, 20, 29-50.

68. Matthews, J. The 4 dimensional language of infancy: The interpersonal basis of art practice. J. Art Des. Educ. 1997, 16, 285-293.

69. Matthews, J. Starting from Scratch: The Origin and Development of Expression, Representation, and Symbolism in Human and Non-Human Primates; Psychology Press: New York, NY, USA, 2011.

70. McBrearty, S.; Brooks, A.S. The revolution that wasn't: A new interpretation of the origin of modern human behavior. J. Hum. Evol. 2000, 39, 453-563.

71. Montagu, A. Toolmaking, hunting, and the origin of language. Ann. N. Y. Acad. Sci. 1976, 280, 266-274.

72. Mora, R.; de la Torre, I. Percussion tools from Olduvai Beds I and II (Tanzania): Implications for early human activities. J. Anthropol. Archaeol. 2005, 24, 179-192.

73. Oakley, K.P. Fossils Collected by the Earlier Palaeolithic Men. In Mélanges de préhistoire, d'archéocivilization et d'ethnologie offerts à André Varagnac; Serpen: Paris, France, 1973; pp. 581-584.

74. Oakley, K.P. Emergence of higher thought 3.0-0.2 Ma B.P. Phil. Trans. R. Soc. B. 1981, 292, 205-211.

75. Pappu, S.; Gunnell, Y.; Akhilesh, K.; Braucher, R.; Taieb, M.; Demory, F.; Thouveny, N. Early Pleistocene Presence of Acheulian Hominins in South India. Science 2011, 331, 1596-1599.

76. Parés, J.M.; Duval, M.; Arnold, L.J. New views on an old move: Hominin migration into Eurasia. Quat. Int. 2013, 295, 5-12.

77. Pickering, T.R.; White, T.D.; Toth, N. Brief Communication, Cutmarks on a Plio-Pleistocene hominid from Sterkfontein, South Africa. Am. J. Phys. Anthropol. 2000, 111, 579-584.

78. Rigaud, S.; d'Errico, F.; Vanhaeren, M.; Neumannd, C. Critical reassessment of putative Acheulean Porosphaera globularis beads. J. Archaeol. Sci. 2009, 36, 25-34. 
79. Sirakov, N.; Guadelli, J.L.; Ivanova, S.; Sirakova, S.; Boudadi-Maligne, M.; Dimitrova, I.; Fernandez, P.; Ferrier, C.; Guadelli, A.; Iordanova, D.; et al. An ancient continuous human presence in the Balkans and the beginnings of human settlement in western Eurasia: A Lower Pleistocene example of the Lower Palaeolithic levels in Kozarnika cave (North-western Bulgaria). Quat. Int. 2010, 223-224, 94-106.

80. Stanistreet, I.G. Fine resolution of early hominin time, Beds I and II, Olduvai Gorge, Tanzania. J. Hum. Evol. 2012, 63, 300-308.

81. Steguweit, L. Intentionelle Schnittmarken auf Tierknochen von Bilzingsleben: Neue lasermikroskopische Untersuchungen. Praehist. Thuringica 1999, 3, 64-79.

82. Tobias, P.V. The brain of Homo habilis: A new level of organization in cerebral evolution. J. Hum. Evol. 1987, 16, 741-761.

83. Tobias, P.V. Olduvai Gorge, Vol. 4. The Skulls, Endocasts and Teeth of Homo Habilis; Tobias, P.V., Ed.; Cambridge University Press: New York, NY, USA, 1991.

84. Tobias, P.V. Tools and Brains: Which Came First? In From Tools to Symbols: From Early Hominids to Modern Humans; d'Errico, F., Backwell, L., Eds.; Wits University Press: Johannesburg, South Africa, 2005; pp. 82-102.

85. Torre, I.; de la; Mora, R. A technological analysis of non-flaked stone tools in Olduvai Beds I \& II. Stressing the relevance of percussion activities in the African Lower Pleistocene. PALEO 2009-2010, Numéro spécial, 13-34.

86. Toth, N. Behavioral inferences from Early Stone artifact assemblages: An experimental model. J. Hum. Evol. 1987, 16, 763-787.

87. Wenban-Smith, F. Handaxe typology and Lower Palaeolithic cultural development: Ficrons, cleavers and two giant handaxes from Cuxton. Lithics 2004, 25, 11-21.

88. White, T.D. Cut marks on the Bodo cranium: A case of prehistoric defleshing. Am. J. Phys. Anthropol. 1986, 69, 503-509.

89. White, T.D.; Asfaw, B.; DeGusta, D.; Gilbert, H.; Richards, G.D.; Suwa, G.; Howell, F.C. Pleistocene Homo sapiens from Middle Awash, Ethiopia. Nature 2003, 423, 742-747.

(C) 2014 by the author; licensee MDPI, Basel, Switzerland. This article is an open access article distributed under the terms and conditions of the Creative Commons Attribution license (http://creativecommons.org/licenses/by/3.0/). 